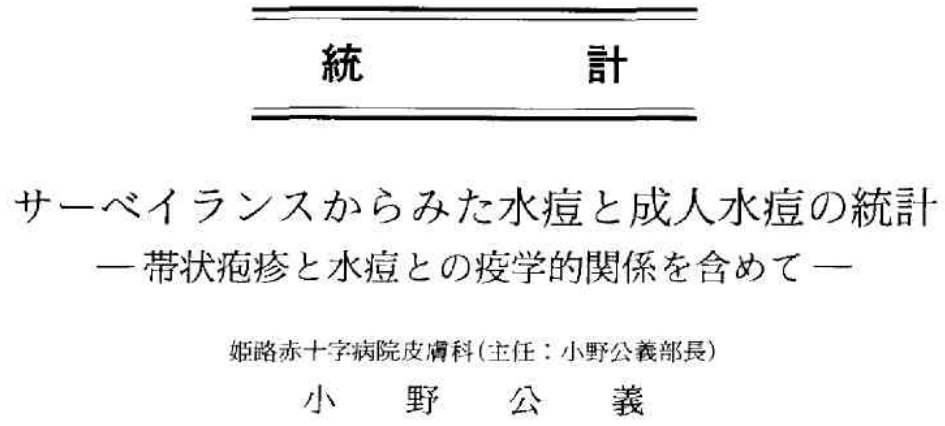

兵庫県皮显科医会が，1986 年 3 月より実施している皮病将ーベイランスから，水痘と成 人水痘の統計を報告した。水溰は 10 月に最低となり，冬加ら初夏にかけて増加する傾向を証 めるが, 成人水痘も水痘の推移とまったく並行した動きを示した。したがって, 水痘全体に 対する成人水痘の割合も，11 12\%という一定したものであった。' 87 年〜92 午の 6 年間に 報告された水痘 4592 例，うち成人水痘 569 例を性別年稀別に検討した。全体の男女比は 1 ： 1.1 で差はないが, 成人水痘に限ると, その比は $1: 1.6$ となり, とくに 20 歳代の女性は 男性の 2 倍以上の比率となった。これ活小児からの感染機会が多いためと考えられる。30 歳 代以上になると性比活逆転し, 男性が女性上り多くなる傾向を示した。带状疱疹と水痘は月 別変化からみても, 年次変化からみても, その発症率が大体に扔いて相反関係となることが わかった。すなわち，一方が滅少したときは他方が増加する関係となっていた。同じウイル スで発症する 2 つの病気が，なぜ発症率については相反関係があるのかは不明である。

\section{はじめに}

1986 年 3 月より兵庫県皮膚科医会 (森秋津会長) では皮膚病のサーベイランスを実施している。そこ で，本論文では 1987 年から 92 年までの 6 年間に定 点から報告去れてきた水痘 4592 例, う方成人水痘 (20 歳以上, 以下同じ) 569 例を中心に, 水痘なかで も成人水痘の統計について報告した。

あわせて，同一ウイルスで発症する帯状泡疹と水 痘が疫学上ではどのような関係があるかを検討し た。

\section{サーベイランスの方法}

サーベイランスの法については，すでに本誌に 報告した文献”に詳しく記載しているので，ここで は省略する。なお, 定点は 1994 年 1 月現在, 24 定 点で表 1 に示す通りである。

\section{結果}

1. '86 年 3 月〜 93 年 10 月までの水痘と成人水 痘の推移(図 1,2)
'86 年 3 月より, 約 8 年間にわたっての水痘の推 移を示した。全体的には冬から初夏にかけてピーク となり，10月前後に最低となる動きを毎年繰り返 していることがわかった。また，20歳以上の成人 水痘の推移を別に図 2 に示したが，水痘全体のグラ フとまったく並行した。縮尺のちがいだけの，ほと んど同じ推移を示していた。

2. 水痘と成人水痘の月別変化(図 3，4）

'87 年から'92 年の 6 年間に斿计る定点からの全報 告数を月別に整理して, 季節的変化をより明確に示 したものが図 3，4である。

冬から初夏に加けて多く，10月には水痘も成人 水痘も最も少なく，縮尺は異なっても2つの四がほ とんど同じカーブを描いていることがわかる。

3. 成人水痘の水痘全体に占める割合（表 2，3）

成人水痘が水痘全体の何\%を占めるのかを調べた のが表 2 である。水痘全体に占める成人水痘の割合 は, ’92 年の $15 \%$ を除けば，どの年も常に水痘全体 の増隇に関係なく，11〜 $12 \%$ の定の比率を占めて いることがわかる。

なお診療所と病院・大学の各外来の水痘全体に占 
表 1 定点所在地と担当者

1994 年 1 月現在, 定点数 24 (大学 2, 注院 5, 影撩所 17)

\begin{tabular}{|c|c|c|c|}
\hline 川西市 & 石田皮阅科医院 & 石田 & \\
\hline 伊乎市 & 松出皮洞科医院 & 松田 & \\
\hline \multirow[t]{2}{*}{ 尼崎芇 } & 今并皮㬝科医院 & 今井 & 靖中 \\
\hline & 松本皮圂科医院 & 松本 & 椧 \\
\hline 宝塚市 & 宝塚市立病院皮店科 & 津田 & 道 \\
\hline \multirow[t]{3}{*}{ 西蕣古 } & 兵庫医科大学波店科 & 喜多里 & 征: \\
\hline & & 森田 & \\
\hline & 法贵皮周科医院 & 法貫 & \\
\hline 芦屋法 & 藤原皮㬝科医院 & 滕原 & \\
\hline \multirow[t]{10}{*}{ 神西市 } & 神戸大学皮㖇科 & 市橋 & 正 \\
\hline & & 凮 & \\
\hline & 唒市民病院皮盛科 & 中村 & 立 \\
\hline & & 谷 & 美 \\
\hline & 雨宮皮渞科医院 & 雨宮 & 直 \\
\hline & 佐々木皮闱科医院 & 佐々才 & 大雅了 \\
\hline & & 貝㴊早 & \\
\hline & 鶴皮唐科医院 & 鶴 圭 & \\
\hline & 森皮消科医院 & 森 & 秋i \\
\hline & 矢野皮消科医院 & 矢野 & \\
\hline 明公市 & 前田皮阅科医院 & 前田 & $\rightarrow$ \\
\hline 洲 本市 & 倉本皮周科医院 & 臬本 & 昌 \\
\hline 豊岡市 & 麻生皮成科医院 & 烋生 & 求 \\
\hline 小野莸 & 田中皮首科医院 & 田中 & 雅 \\
\hline \multirow[t]{2}{*}{ 加古川宋 } & 兵庫県立加古川病院皮度科 & 本田 & 千 \\
\hline & 西岡皮噳科医院 & 西風 & 五 \\
\hline 加西市 & 加西市民病院皮䖉科 & 源田 & \\
\hline \multirow{2}{*}{ 姫 路市 } & 姫路赤十字病院皮㬝科 & 小野 & 公事 \\
\hline & 石井皮周科医 & 石井 & \\
\hline
\end{tabular}

める成人水痘の割合は，患者層の羑異のために大き く異なっており, 表 3 で示すように病院・大学では 診療所に比較して，成人水痘が非常に多いことがわ かる。

4. 水痘の性別年齢別分布（図 5)

'87 '92 年の 6 年間での報告例数 4592 例を性別 年藏別に分類した。0 9 歳の子どもに多いのは当 然として, 成人では 20 歳代に多く, 次いで 30 歳代 で,あとは急速に減少する。

性別では全体としてはやや女性が多い。しかし， 年代別にみると，10 歳代，20歳代なかでも 20 歳代 は断然女性に多く, 30 歳代以降ではやや男性に多 くなる傾问が認められた。

5. 帯状疮疹と水痘との疫学的関係

この2疾患は同一ウイルスで発症するが, 疫学的 には発症時期についてこの 2 疾㭧で何らかの相関関 係があるかどうかを検討した。

a) 带状疮疹と水痘の增滅の月別変化(図 6)

'87 年から'92 年の 6 年間について, 月別に報告例 数を調ベて,この2疾患を同一グラフ上に記したの が図6である。2疾患の関係は大体において一方が 減少す札ば他方が增加するという相反関係になって

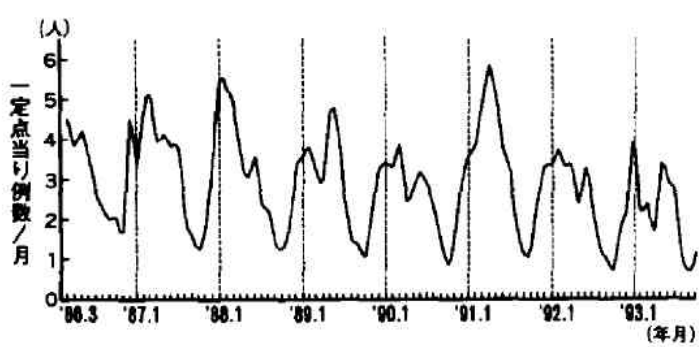

图1 水痘0)推移(1986.3 迆93.10)

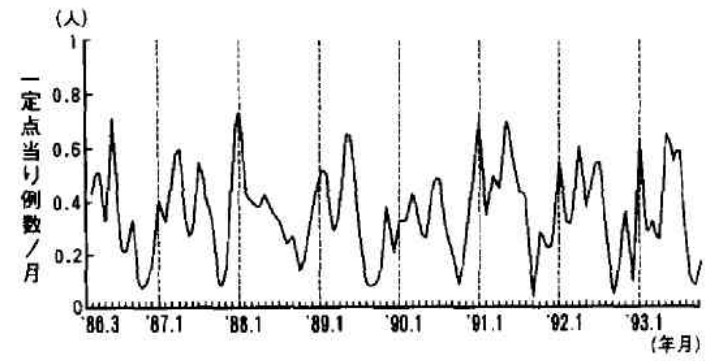

図 2 成人水揸の推移 $(1986.3 \sim 1993.10)$

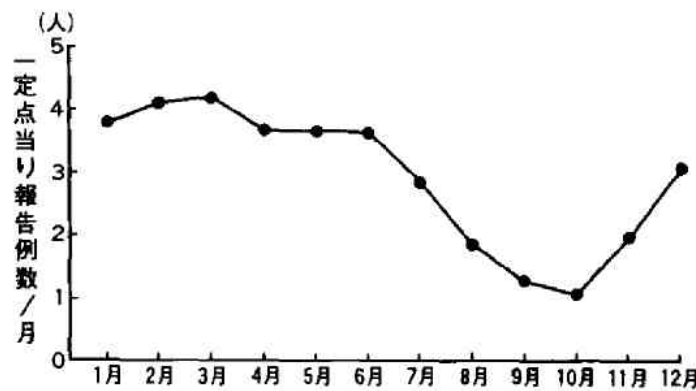

図 3 水㢄の月別, 一定点当り平均報告例数 (1987 1992)

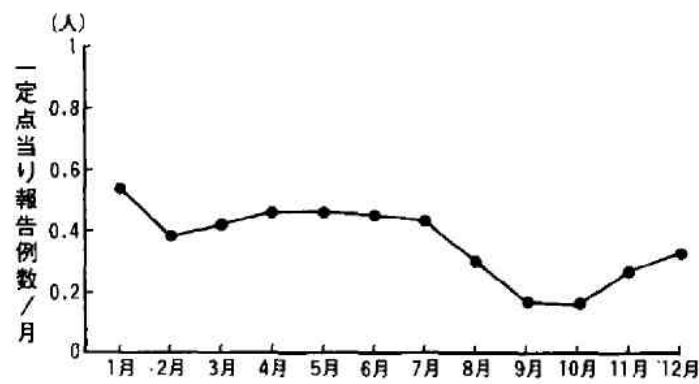

图 4 成人水痘の月別, 一定点当り平均報告例数 (1987 1992) 


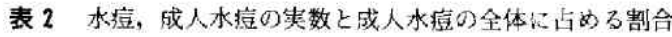

\begin{tabular}{|c|c|c|c|c|c|}
\hline 年 & 水痘の報告総数 & $\begin{array}{c}\text { 一定点当りの吕月, } \\
\text { 平均報告例数 } \\
\end{array}$ & $\begin{array}{l}\text { 成人水痘の } \\
\text { 報告総数 }\end{array}$ & $\begin{array}{c}\text { 一定点当りの1力月, } \\
\text { 平均報告例数 }\end{array}$ & $\begin{array}{c}\text { 成人水㾇の水痘全体 } \\
\text { に占める割合 }\end{array}$ \\
\hline 1987 & 832 例 & 3,26 例 & 96例 & 0.38 例 & $11.5 \%$ \\
\hline 1988 & 826 & 3.20 & 95 & 0.37 & 11.5 \\
\hline 1989 & 723 & 2.86 & 8.5 & 0.34 & 11.8 \\
\hline 1990 & 684 & 2.56 & 88 & 0.33 & 12.9 \\
\hline 1991 & 889 & 3.32 & 109 & 0.41 & 12.3 \\
\hline 1992 & 638 & 2.43 & 96 & 0.37 & 15.0 \\
\hline 計 & 4592 & & 569 & & $\overline{12.4}$ \\
\hline
\end{tabular}

（注：計算上は，年度によって定点数が脱洛もあって異なっていることがあることに注意）

表 3 猃橑所と病院・大学に抬ける成人水滨の水㜔全体に 占める割合の差異について

\begin{tabular}{|c|c|c|}
\hline & $\begin{array}{l}\text { 診撩所における } \\
\text { 成人水㾇の\% }\end{array}$ & $\begin{array}{c}\text { 病院・大学に节ける } \\
\text { 成人水湍の\% }\end{array}$ \\
\hline $\begin{array}{l}1987 \sim 89 \text { 年の } \\
3 \text { 年問の地 }\end{array}$ & $7.0 \%$ & $40.9 \%$ \\
\hline
\end{tabular}

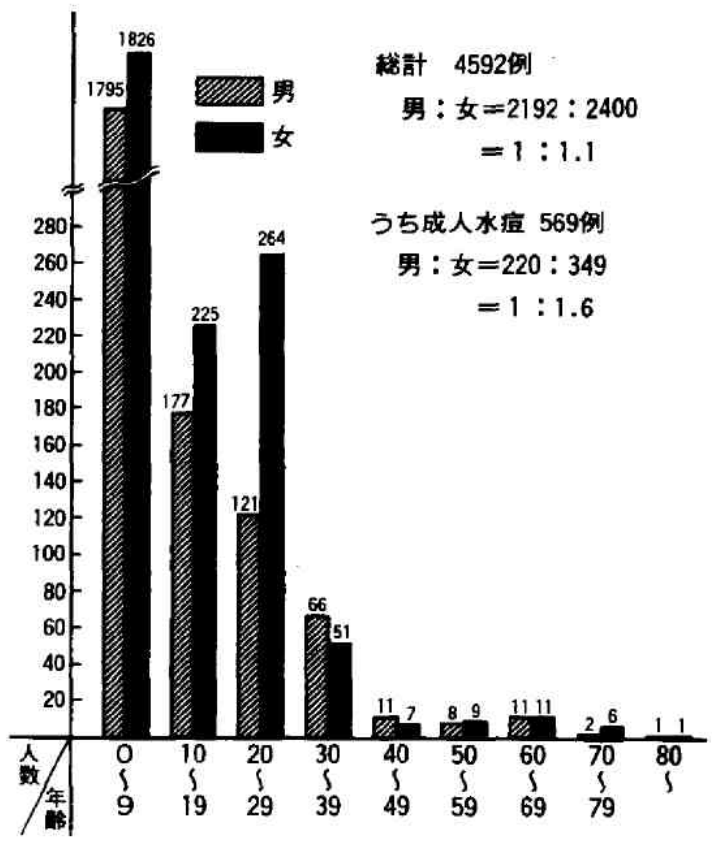

図 5 水㾤の性別年剈別分布 $(1987 \sim 1992$ 年 $)$

\section{いることがわかる。}

b) 带状疮疹と水痘の增隇の月別変化（0～9 歳の 小児の場合) (図 7)

水痘注とくに小児に多く，帯状疱疹忯児に少な いと，なお一般にいわれているので，0９歳の小

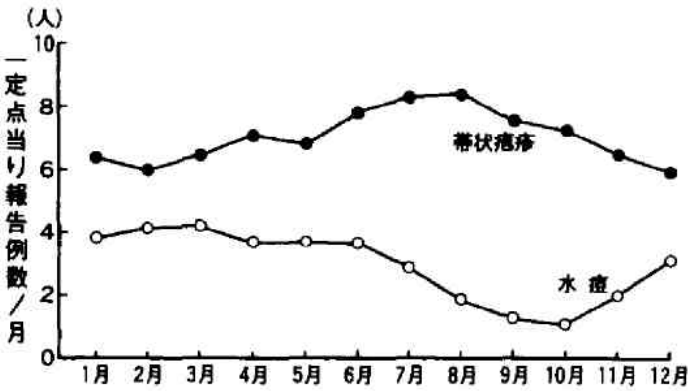

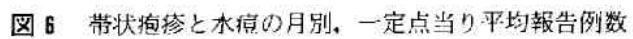
(1987 1992)

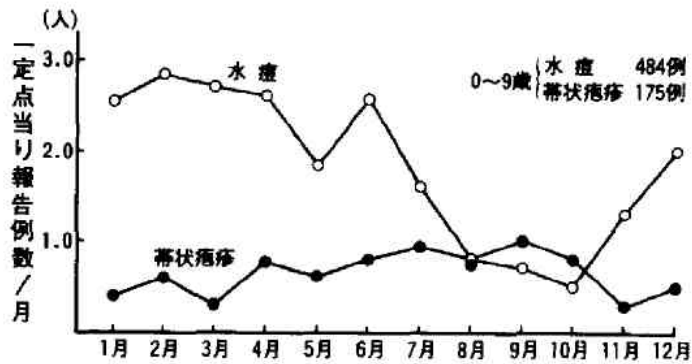

图 7 帯状疮轸と水㢄 月月別，一定点当り平均報告例数 (0〜9藏について) (1992 年)

児の場合でも，この2踟患において相反関倸がある かどうかを1992年を例にとって調べた。図てに示 すように，図 6 ほど明確ではないが，やはり一方が 減少すれば他方が增加する関係にあることがわかっ た。

c) 帯状疮疹と水痘の増減の年次変化(図 8)

2 疾患の相反関係が，月別変化だけではなく，年 次変化でも成立するかどうかを検討した。图8に示 す通り，大体において一方が多くなった年は他方が 滅少する年になることがわかった。 


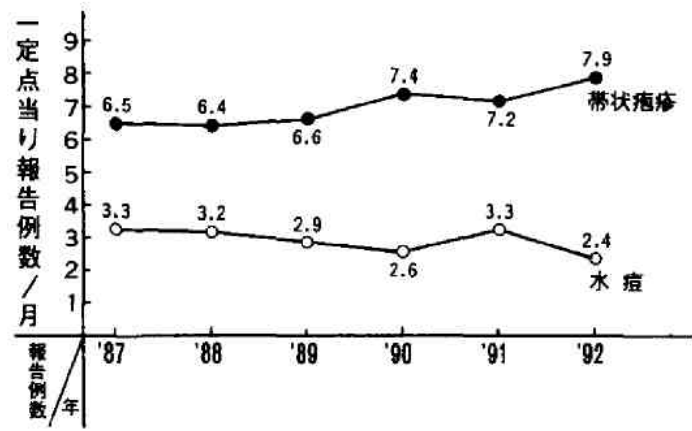

图 8 水痘と带状䳐翏の年度別, 一定点当り, 一力月間 の平均報告例数

\section{かんがえ}

水痘がどのように流行し，どのように增隇推移し ているか的厚生省を中心とするサーベイランスで その詳練が明らかとなっている。しかしそれは主と して小児科関するものであって，成人水痘がどの くらい発症しているか，また皮唐科領域では水痘が どのくらい経験されているかといったことについて はほとんど未調査といってよい。そこで，兵庫徂皮 周科医全で実施しているサー-ベイランスの統計に よって, 成人水痘がどのような動きを示している か，また，带状疱疹と水痘とがどのような関保にあ るのかを調查した。

1. 水痘と成人水痘の流行の推移

水痘が 1 6月ごろまでをピークとし，10月には 最低となり，また増加するパターンを毎年繰り返し ていることはすでに周知のことである6!。ただ，こ こに示したサーベイランスデータ倣皮科の医療機 関のみを定点として実施しており，小児科領域は考 えられていないので，水痘の実数，とくに0〜9歳 代の症例数㹥筆者の統計の数倍は多いものとして デー夕を検討していく必要があると思われる。

さて図 1 と図 2 を比較するとわかるように，成人 水痘の推移縮尺は異なるものの，水痘全体の動き とまったく並行した動きを示していることがわか る。

また’ 87 年〜'92 年の 6 年間の水痘と成人水痘の全 報告数を月別に整理してその推移をみた（図 3，4） が, やはり, 成人水痘は水痘全体の季節変化とまっ たく同じ動きをしていることがわかるであるう。

成人水痘が最近增加しているという報告 ${ }^{2 / 31}$ があ るが, '86 年 3 月から’92 年までの期間に限っていう
ならば，成人水痘は水痘全体の動きに完全に比例し ながら增減を繰り返しているだけで，特別に成人の みが小兄に比較して突出して増加しているわけでは ないことがわかる。

2. 成人水痘の水痘全体に占める割合

では水痘全体に対して成人水痘はどのくらい発症 するのであろうか。小児科領域からの統計では，も ちろん何も明確にできないか゚，皮虑科領域の統計で は小児が少なくなるため，あくまで皮埇科領域から みた統計という限定つきでの割合であるが，表 2 に 見る通り, '92 年除け结成人水痘汕常に $11 \sim 12 \%$ の一定の比率を占めていることがわかる。今後，こ の割合がどう推移するかを見守っていくことが必要 上思われる。

さて成人水瘦は重症になる傾向 ${ }^{45)}$ があるので， 患者注診療所より病院・大学を選ふ傾向が高くなり, 一方小児の水痘は軽症が多く, 近くの診療所を選ぶ 傾向が高いと考えられるので，当然，この 2 種の医 療機関内においては，成人水痘の占める率に差異が 出てくると思われる。

そこで診療所と病院・大学の 2 群に定点を分類し て，それぞれに成人水痘の占める率を計算したもの が表 3 である。病院は $40 \%$ を成人水痘が占め, 診 療所は7\%しかない。以上のデータから成人水痘の サーベイランスは, 病院・大学定点と診療所定点と を，どう設定して観察していくべきかの大切さを示 していると思われる。ちなみに，重症化した水痘に

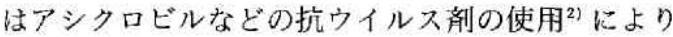
著効を旺するようになったことは喜ばしい。

3. 水痘の性别年藏別分布

図 5 に示すように'87〜'92 年の 6 年間の水痘 4592 例の約 $80 \%$ 0 〜歳の小兒で占められており，そ の残りのほとんどが 10〜30 歳代であるという年粭 分布となっている。20歳以上の成人水痘の割合は $12.4 \%$ あった。

性別をみると 20 瓷代まではいずれも女性が多く, なかでも20歳代は男性の 2 倍以上も女性が多く なっている。これは水㾇の子どもに接する機会が多 にためであろうと思われる。30歳代以上になると 男性が女性よりや扔多くなる傾向を示すが，これは すでに笠井 ${ }^{31}$ が指摘している通りである。しかし理 由がなぜかはよくわからない。すでに筆者が報告し た帯状佨疹についての論文”の中で，帯状疱疹はゃ や女性に多いと報告したが，その理由のひとつとし て, 水痘が 10 藏代, 20 歳代で志, 男性よりも女性 
がかなり多いということで説明がつくと考えてい る。

4. 带状疱疹と水痘の疫学的関俰

この両疾患が同一ウイルスによって発症する病気 であることは周知の通りであるが，従来带状疮疹は 季節的変化はないとされ, 水痘は前述した通りの推 移を示すことが明確となっている。

しかしすでに報告1しした帯状疱疹の推移のグラフ と水痘のそれとを比較したとき，一見して水痘が減 少すれば帯状疮疹が增加するという相反した動きを 示すことが読みと枦。笠井7もすでに指摘してい ることであり，さらにここではどこまでこの仮説が 正しいかを検討してみた。

'87〜92 年の 6 年間の月別の動きをこの 2 疾患同 時に示したのが図6である。より鮮明にこの両者が 一方が増えれば一方が減少するという関係になって いることがわかる。しかし厳密にみれば帯状疮疹は 8 月が最高值を示しているのに, 水痘は 8 月ではな くて10月が最低值を示すというようにわずかの ずれはあるが全体的には增えれば隇るという関係が あるといってよいと考えられる。

水痘は小児に多く带状疱疹は今のところ小児に少 ないとされているので、この関係が小児においても

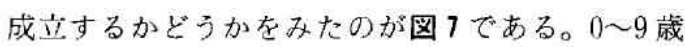
の小児の’92 年のみについての分析であるが，やは り，同様の関係が諗められた。

さらに,この関係を年次的に調べたのが図 8 であ る。年次的にみても一方が少ない年は, 他方が多い 年となっていることがわかる。しかも图8をみても わかるように, 減少した数だけ一方が增加するとい う関係になっており，両者を加文ると常に 9〜10の 数字になる。つまり皮骨科の各医療機関は每月平均 して水痘と带状疱疹の患者を合計して 9 10 人経験 しているということになる。もちろんこの関係は皮 膚科領域では，という限定がつくと考えられる。小
児科領域では水痘の例数が皮䖉科領域より数倍多い のであるから，雨者を加算して一定数になるかどう かは今後検討してみないとわからないであろう。图 フからみても，一定数になるということは無理であ ると考えられる。しかしなぜこの両疾患はこういっ た相反関係を同一ウイルスで生ずる病気であるのに 示すのであろうか。まったく不明といってよく、こ れからの基礎的研究に期待したい。またこういつ た統計的事実がどこまで普遍的なものであるかを関 係各領域でさらに追求していただければありがたい と思っている。

（最後に, 以上の の全員の協力によって作ることができたものでるるとを付 記するとともに，あらためて，定点を担当して下きった方及 をはじめとして，全会員の皆様に感謝申しあげま守。

ただし、デー夕の分析, 検款については, 筆者に全鿓任が

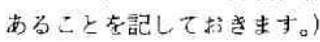

\section{文献}

1）小野公義：サーベイランスからみた带状狍抮の統計. 西日皮有 56:763-768, 1994.

2）赤城久美子ほか: 成人水痘の統計的観察. 皮跕休 $29: 937-943,1987$.

3）笠井達也：急性発疹症 $の$ 変遷. 皮藏病站療 10 : 217-224, 1988 .

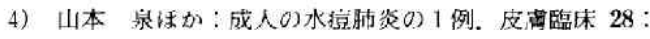
$574-575,1986$.

5）木村恭一ほか：成人水痘の DICに上る死亡例。皮薄臨 床 $28: 856-857,1986$.

6）岩崎哲巳，山岸 稳：最近の水痘感染の問題点と対策. 臨と研究 $70: 2421-2425,1993$.

7）笠井達也：感染症の定点笅測。皮膚臨床 25:751-763, 1983.

(平成 6 年 2 月 1 日 受付·平成 6 年 2 月 3 日 採用決定·特揭)

別别請求先： $\bar{\top} 670$ 姫路市龍野町 5-30-1 姫路赤十字病院皮庯科 小野 公義 


\title{
A Statistical Study of Chickenpox and Adult Chickenpox from the Viewpoint of Surveillance \\ — Including the Epidemiological Relationship between Herpes Zoster and Chickenpox-
}

\author{
Kimiyoshi ONO \\ Department of Dermatology, Himeji Red Cross Hospital \\ Himeji 670, Japan (Chief: Dr. K. Ono)
}

Hyogo Society of Clinical Dermatologists reported the statistics of chickenpox and adult chickenpox on the basis of the skin disease surveillance data, which had been collected since March 1986.

It was observed that the incidence of chickenpox tended to be the lowest in October and there after in creased from the winter to early summer. Further more, the incidencc of adult chickenpox completely changed in parallel with that of chickenpox. Thus, the proportion of the cases of adult chickenpox to the cases of all chickenpox always remained fixed (11\% to 12\%). Over a period of 6 years (1987 to 1992), the reported 4,592 cases of chickenpox (including 569 cases of adult chickenpox) were evaluated according to sex and age. The entire proportion of males to females was found to be a ratio of $1: 1.1$. In the cases of acult chickenpox alone, the proportion was $1: 1.6$, without indicating any remarkable significant difference between female and male. Especially in regard to female in their twenties, the cases of adult chickenpox were 2 times those of male in their twenties. The results are ascribable to the fact that there are many chances to become infected from childhood. In regard to the patients above thirty, the proportion of male to female was reversed. In other words, the number of male cases tended to be higher than the female cases. The incidence of herpes zoster was found to be almost the opposite of chickenpox in view of the monthly and yearly changes. In brief, the incidence of one disease in creased while the incidence of the other disease decreased. It is unknown why there is an inverse relation between the two types of incidence for those two diseases which are caused by the same virus. 